\title{
Promoting Students' Perceived Self-Efficacy towards 21st Century Skills through Everyday Life-Related Scenarios
}

\author{
Helen Semilarski * (1), Regina Soobard (1) and Miia Rannikmäe \\ Centre for Science Education, University of Tartu, 60532 Tartu, Estonia; regina.soobard@ut.ee (R.S.); \\ miia.rannikmae@ut.ee (M.R.) \\ * Correspondence: helen.semilarski@ut.ee
}

check for updates

Citation: Semilarski, H.; Soobard, R.; Rannikmäe, M. Promoting Students' Perceived Self-Efficacy towards 21st Century Skills through Everyday Life-Related Scenarios. Educ. Sci. 2021, 11, 570. https://doi.org/ 10.3390/educsci11100570

Academic Editor: Marius Boboc

Received: 4 August 2021

Accepted: 16 September 2021

Published: 23 September 2021

Publisher's Note: MDPI stays neutral with regard to jurisdictional claims in published maps and institutional affiliations.

Copyright: (c) 2021 by the authors. Licensee MDPI, Basel, Switzerland. This article is an open access article distributed under the terms and conditions of the Creative Commons Attribution (CC BY) license (https:// creativecommons.org/licenses/by/ $4.0 /)$.

\begin{abstract}
Interdisciplinary science learning can play a central role in promoting students' 21st century skills. However, students tend to have low perceived self-efficacy towards 21 st century skills, thus limiting the application of their actual scientific competence. This study seeks, based on a 1.5-year intervention study, to promote students' perceived self-efficacy towards 21st century skills through science learning compared to a non-experimental group. During the intervention, everyday liferelated scenarios were utilized, with students guided to create core idea maps. Data on students' perceived self-efficacy were collected before and after the intervention. Results showed that students' perceived self-efficacy towards 21st century skills changed in a significantly positively way after the intervention.
\end{abstract}

Keywords: core idea maps; everyday life-related scenarios; perceived self-efficacy; 21st century skills

\section{Introduction}

Commercial enterprises increasingly make use of new technologies and encourage their employees to work as a collective team to create new ideas, products and services [1,2]. Not surprising, therefore, business leaders, politicians and intellectuals, from a variety of backgrounds, value students who possess a wide range of skills [3,4]. A major education goal is thus providing students with a set of critical skills, often referred to as 21st century skills, enabling them to be successful in the global market $[5,6]$. Such skills are of particular importance when faced with a range of societal problems to be addressed, but which also require abilities to be flexible, able to solve complex problems, make justified decisions based on sound argumentation and to communicate effectively in raising global awareness [2,7]. In fact, for students to adapt to a world that is rapidly changing, the development of 21st century skills is seen as essential [8]. Twenty-first century skills refer to the knowledge and skills that are critically important for student success in today's world and in their further studies [1,3].

This research explores students' perceived self-efficacy towards 21st century skills, seeing this as important to support their perceived self-efficacy. Bandura (1986) defines perceived self-efficacy as a person's own evaluation of their capabilities to perform a task, or to reach a desired goal [9]. For this reason, perceived self-efficacy is utilized as a suitable way to determine students' perceptions of their 21st century skills.

\subsection{Value of 21st Century Skills}

Twenty-first century skills [4] are often referred to as work and life skills [10], or generic skills [11], and relate to a broad set of knowledge, skills, work habits and character traits that are believed to be critically important for success in today's world [12,13]. They emphasize the importance of being able to apply knowledge rather than simply recalling facts or concepts, undertake critical thinking for solving problems or making decisions $[1,14]$ and enable preparation for occupations that do not yet exist $[2,15,16]$. 
According to Haug and Mork [17] and Tight [18], such skills are required to enable an individual to face challenges of the 21st century and are thus seen as important to be emphasized and developed in different lessons. Twenty-first century skill gains are seen as necessary in all academic subject areas, not least because they are seen as transferrable between different subjects and real-life situations, but also in all educational, career, and civic settings throughout a student's life $[4,19,20]$. To develop 21st century skills, education needs to shift from simply preparing students for careers to enhancing abilities for transference of learning across a variety of roles [2,21].

\subsection{Categorizing 21st Century Skills}

The literature sees other terms and definitions associated with the 21st century skills, e.g., soft skills, life skills, critical skills, digital skills or transversal skills are often regarded as synonyms for 21st century skills, despite some significant diversity across a range of personal, professional and practical attributes $[1,3,5]$. Nevertheless, there is general agreement among researchers on the need for new forms of learning to tackle global challenges $[17,18]$. However, despite this consensus, there is no unique or single approach to a definition or categorization of 21st century skills and the literature is also not conclusive on the difference between 21st century skills and other related skills (e.g., transferable skills) $[1,3,5]$. Thus, there is a need to specify which 21 st century skills are being researched. For developing students' 21st century skills, one recommendation is also to concentrate on a task and have a centric focus [1].

In a general framework, 21st century skills can be categorized into three main groups: life and career skills; learning and innovation skills; and information, media and technology skills [4]. Binkley and his colleagues [22] went further, using four categories labelled as ways of thinking, ways of working, tools for working and living in the world, and identified ten skill components, namely: creativity and innovation; critical thinking, problem solving, decision making, learning to learn, metacognition communication, collaboration, information literacy, ITC literacy, citizenship, life and career and personal and social responsibility $[23,24]$.

The promotion of scientific literacy and, within this, the promotion of multiple skills, is central to a competency-based curriculum (Estonian Government, 2011). The skills associated with enhancing scientific literacy are linked to a number of factors, including:

- Understanding the nature of science and the subject (including the changeability of scientific knowledge and responsible citizenship);

- Personal development, especially that associated with self-management and selfefficacy (including a mindset for scientific research);

- Acquisition of social skills, such as reasoned decision making and resolving problems (including cognitive and problem-solving skills, as well as critical thinking).

In specifying the 21st century skills for this research [10,22,25], the following five categories are preferred:

- Cognitive and problem-solving skills—needed in the acquisition of knowledge, manipulation of information and reasoning. Students need to be able to solve complex problems as they occur;

- Critical thinking - mode of thinking about any subject, content or problem in which a thinker improves the quality of their thinking by skillfully reasoning, analyzing, synthesizing and evaluating information to reach an answer or conclusion;

- The changeability of scientific knowledge-understanding how scientific knowledge is constructed;

- Responsible citizenship - having knowledge about his/her role in the community, state and the world;

- Mindset for scientific research —organized mindset that ensures proper thinking (considering evidence, flexibility, methodological approaches and accuracy). 


\subsection{Twenty-First Century Skills to Promote Interdisciplinarity Based on Core Ideas}

A perceived key to promoting students' 21st century skills is the implementation of interdisciplinarity, particularly within science subjects [26-28]. For example, not only is there a need to put greater emphasis on collaboration with colleagues, possibly through conducting interdisciplinary subject projects, or promoting knowledge integration though problem-solving [29], but there is also a need to develop core ideas, which are applicable and transferable across different subjects [29,30]. In fact, within science teaching, core ideas can form a unified scientific framework for various curriculum-specified topics. Such frameworks, for example, are seen as energy conversion, chemical reactions, genetic variation, weather and climate [10,31]. Core ideas have broad importance within and across science lessons, are relatable with globally challenging concerns and provide a key tool for conceptualizing and investigating complex problems [29,30]. Furthermore, promoting the interdisciplinarity of 21st century skills between different subjects is an effective and relevant way to address core ideas [32]. Recognizing and conceptualizing core ideas (such as weather and climate) are especially important for students and teachers when relating knowledge from different science lessons in order to solve problems, or demonstrating conceptualizations of certain phenomena $[29,30]$.

\subsection{Context-Based Approach via Scenarios}

One approach to developing 21st century skills, as well as enabling the development of student confidence in developing core ideas through science learning, is though developing these skills in relation to everyday life [12]. Utilizing everyday life-related scenarios as a context-based approach enables the development of interdisciplinary core ideas, plus their applicability to everyday life, which potentially increases the relevance of science learning for students $[26,33]$. In such an approach, a scenario is a teaching strategy that involves real-world situations, or concerns in which students are involved in performing relevant tasks and play specific roles [33]. Scenarios can relate to a wide range of situations. For example, a scenario can be based on a vaccination situation requiring justified argumentation (related to critical thinking), or undertaking group-work on how modern solar technologies can help improve the well-being of people in developing countries (related to responsible innovation).

\subsection{Student Gains in 21st Century Skills Are Based on Their Perceived Self-Efficacy Beliefs}

To promote students' 21st century skills, it is important to support their perceived self-efficacy. This is seen as a person's evaluation of their abilities to organize or perform activities that require the use of skills [34]. Thus, involving students in actual acting and demonstrating skills in real world scenarios is suggested as one way to relate to perceived self-efficacy beliefs. Yet, previous studies have indicated that students have low perceived self-efficacy towards 21st century skills, such as problem solving and critical thinking $[10,12,34]$. Scenarios are thus seen as enabling active learning opportunities, which engage students in the learning process [35] and promote perceived self-efficacy beliefs. Such active learning opportunities can relate to posing questions in the classroom, argumentation, group projects, role-playing, debates, etc. [36,37].

The goal of this research is to evaluate the impact of the role of scenarios as a contextbased approach in science lessons to promote students' perceived self-efficacy towards 21st century skills. The adopted approach is via an intervention including everyday life-related scenarios (each involving students in creating core idea maps). The core idea maps are intended to conceptualize fundamental ideas in science (e.g., energy conversion), including the paying of due attention to science-related knowledge and appropriate 21st century skills [38]. The design of the core idea maps follows the mind-mapping method, which has been shown to support students' knowledge construction [10,39]. Additionally, each core idea is linked to an everyday life-related scenario. For example, with the core idea on genetic variation, students at first create their core idea map and then participate in a classroom debate or role-play about whether or not to vaccinate. 
The following research question is put forward:

RQ1: How does the perceived self-efficacy of students towards the development of 21st century skills change after a 1.5-year intervention when compared with the perceived self-efficacy of a similar, non-experimental student group?

\section{Methodology}

\subsection{Sample and Study Design}

The sample consisted of an experimental and a non-experimental student group.

\subsubsection{Experimental Group}

The research sample for the experimental group was formed by 209 students from five schools that participated in the intervention. Pre-intervention data were collected through a pencil and paper format before January 2019 from these students (grade 10 students) and immediately after a year-and-a-half intervention in May 2020 (post-questionnaire, grade 11 students) using a Google Form template (this made it possible to collect data during the COVID-19 epidemic).

\subsubsection{Non-Experimental Group}

In the non-experimental group, 162 students from five schools participated. Schools in both the experimental and non-experimental groups were similar, based on school location and the number of students per school. While only the experimental group completed a pre-questionnaire, data were collected at the end of grade 11 (May 2020) from both the experimental and non-experimental groups, with each student completing an online questionnaire, which took approximately $20-25 \mathrm{~min}$ to complete.

\subsection{Instrument Design}

This research used a previously developed questionnaire [10,34,37]. The pre-and post-questionnaire consisted of 24 statements obtaining data on students' perceived selfefficacy towards 21 st century skills, using a 4-point scale (1-I totally disagree; 2-disagree; 3-agree; 4-I totally agree).

As a result of prior validation [10,34], the created instrument was divided into five 21st century skill factors giving factor names and example statements:

- Cognitive and problem-solving skills-“I can use creative thinking to solve scientific problems";

- Critical thinking-“I can critically evaluate the quality of information";

- The changeability of scientific knowledge-“'In my opinion scientific knowledge can change";

- Responsible citizenship_- "When I make decisions, I consider the positive and negative consequences towards the natural environment";

- Mindset for scientific research-“In my opinion, carefully collected data will give perfect knowledge".

Table 1 indicates how these factor sets of 21st century skills were implemented during the intervention in science classes.

\subsection{The Intervention}

To connect the learning of science content with 21st century skills, everyday liferelated scenarios (each involving students in creating core idea maps) were implemented in science lessons. The core idea maps were intended to depict the development of important, conceptualized fundamental ideas in science, including due attention to the science-related knowledge and appropriate 21st century skills [37]. The design of the core idea maps to be developed followed the mind-mapping method, which has been shown to support students' knowledge construction [10,37]. 
Table 1. Intervention design.

\begin{tabular}{|c|c|c|c|c|c|}
\hline Intervention & Core Idea Map & $\begin{array}{l}\text { Everyday Life-Related } \\
\text { Scenario }\end{array}$ & $\begin{array}{c}\text { Career } \\
\text { Introduction }\end{array}$ & Outcomes From Class & $\begin{array}{c}\text { 21st Century Skills } \\
\text { Promoted }\end{array}$ \\
\hline \multirow{2}{*}{1} & Genetic variation & "Vaccination" & Doctor & \multirow{2}{*}{$\begin{array}{l}\text { Students creating core idea maps by drawing the connections } \\
\text { (working in pairs). } \\
\text { Presenting debate and role-play (involvement of various stakeholders, e.g., } \\
\text { doctors, the agency for medicines) in the class about whether to } \\
\text { vaccinate or not. } \\
\text { Conducting the experimental planning and enacting to determine reaction } \\
\text { rate dependence of the nature of metal. }\end{array}$} & $\begin{array}{c}\text { Cognitive and } \\
\text { problem-solving skills }\end{array}$ \\
\hline & Chemical reactions & "Chemical reactions" & Chemist & & $\begin{array}{l}\text { Mindset for scientific } \\
\text { research }\end{array}$ \\
\hline \multirow{4}{*}{2} & Land surface change & "Future" & Mining engineer & \multirow{4}{*}{$\begin{array}{l}\text { Students creating core idea maps by drawing the connections } \\
\text { (working in pairs). } \\
\text { Group-work following an overview of the changes of the land in the oil } \\
\text { shale mines (Ida Virumaa) on topic what would life be like in Ida Virumaa } \\
\text { in 2050? Presenting the made posters in class. } \\
\text { Group-work on topics: 1) What are the consequences of the unequal } \\
\text { distribution of food in the World? 2) How can these issues be } \\
\text { prevented or avoided. } \\
\text { into a rainbow. } \\
\text { Constructing in groups a spectrometer and using it to simply turn the light } \\
\text { Students explaining a video about surface tension in space (shown by } \\
\text { NASA astronauts). Competition in class: 1) determine the number of drops } \\
\text { of water you are able to put on top of a penny using a pipette; } 2 \text { ) what is } \\
\text { the phenomenon behind this experiment, why can the penny hold many } \\
\text { drops of water? }\end{array}$} & $\begin{array}{c}\text { Cognitive and } \\
\text { problem-solving skills }\end{array}$ \\
\hline & Heredity and DNA & "Nutrition" & Nutritionist & & $\begin{array}{c}\text { Critical } \\
\text { Thinking skills }\end{array}$ \\
\hline & Motions and waves & "Galileo" & Scientist & & $\begin{array}{l}\text { The changeability of } \\
\text { scientific knowledge }\end{array}$ \\
\hline & Characteristics of substances & "Water properties" & Astronaut & & $\begin{array}{c}\text { Mindset for } \\
\text { scientific research }\end{array}$ \\
\hline \multirow{3}{*}{3} & Energy conversation & "Solar panels" & Engineer & \multirow{3}{*}{$\begin{array}{c}\text { Students creating core idea maps by drawing the connections } \\
\text { (working in pairs). } \\
\text { Group-work on how modern solar technologies can help improve the } \\
\text { well-being of people in developing countries. } \\
\text { Discussion in a group based on given articles to find both pros and cons } \\
\text { that support or refute claims about the human impact on climate. The } \\
\text { group were guided to create a poster or short video to convey their } \\
\text { arguments and objections. }\end{array}$} & Responsible citizenship \\
\hline & Weather and climate & "Climate change" & Paleoclimatologist & & Critical thinking skills \\
\hline & Systems & & & & \\
\hline
\end{tabular}


The scenario-led interventions illustrated in Table 1 were developed by Author 1 and her colleagues [37]. In total, each experimental group student was asked to create 10 core idea maps during the intervention period with each map (except maps sought on models and on systems), based on an everyday life-related scenario (a total 8 scenarios), with each scenario involving the promotion of 21st century skills deemed to be related to the various learning tasks. As the model and system core ideas are more interdisciplinary and not specific to an everyday life situation, no separate scenarios were created, and relevant learning was covered within the teaching using the 8 everyday life-related scenarios. To further raise student's motivation regarding science studies, a description of relevant science-related careers was included in the everyday life-related scenarios.

The intervention was divided into 3 steps (Table 1), each paying particular attention to those skills which, from previous studies [10], indicated students' lower perceived selfefficacy. This was undertaken by including the promotion of these skills in the intervention twice (Table 1). These skills were:

- Cognitive and problem-solving skills;

- Critical thinking;

- Mindset for scientific research.

Other skills that, from previous research (Author 1 et al., 2019), students were shown to attain a higher perceived self-efficacy, were included in the intervention only once (Table 1). These skills were:

- Responsible citizenship;

- The changeability of scientific knowledge.

\subsection{Data Analysis}

Descriptive statistics (means, standard deviations), statistical significance and reliability were undertaken using SPSS version 23. The mean scores of students' perceived self-efficacy towards 21st century skills were compared and analyzed using paired sample t-test. Data were checked for normal distribution (data fitting a bell-shaped curve), and that the data were not bi-modal. The statistical program Mplus (Version 7) [39] was used for confirmatory factor analysis (CFA).

\subsection{Validity and Reliability}

The validity and reliability of the created instrument and methodology used as validation were determined as shown in Table 2.

Table 2. Validation and reliability of the instrument created for this research.

\begin{tabular}{ccc}
\hline Instrument/Method & Validity/Reliability & Used Validation/Reliability Method \\
\hline & Content validity & $\begin{array}{c}\text { Expert opinion method; agreement of 14 independent } \\
\text { experts in the field of science education }\end{array}$ \\
\cline { 2 - 3 } $\begin{array}{c}\text { Students' perceived self-efficacy towards } \\
\text { 21st century skills/4-point } \\
\text { scale questionnaire }\end{array}$ & $\begin{array}{c}\text { Analysis of Estonian science curriculum [40] and } \\
\text { syllabus to ensure that items are valid in terms of } \\
\text { expected learning outcomes; Mplus CFA }\end{array}$ \\
\cline { 2 - 3 } & Construct validity & $\begin{array}{c}\text { Cronbach alpha } 0.81 \text { over the sample, with each } \\
\text { factor over 0.70; Mplus CFA was used to determine } \\
\text { the suitability of the internal structure [41] }\end{array}$ \\
\hline
\end{tabular}

\subsection{Ethics}

The goal of the research and the use of its outcomes were explained to students, parents and school headmasters. Participation in the study was voluntary for the students and permission from the parents was asked. All collected data were stored keeping in mind the principles of confidentiality. 


\section{Results and Discussion}

3.1. Experimental Group Pre- and Post-Questionnaire CFA Comparison on Perceived Self-Efficacy towards 21st Century Skills

The conducted CFA analysis revealed similar changes occurred in the five 21st century skills factors (Table 3; Appendix A):

- Cognitive and problem-solving skills;

- Critical thinking;

- The changeability of scientific knowledge;

- Responsible citizenship;

- Mindset for scientific research.

Table 3. Pre- and post-questionnaire CFA comparison on perceived self-efficacy towards 21st century skills by the experimental group $(\mathrm{N}=209)$.

\begin{tabular}{|c|c|c|c|c|c|c|c|c|c|}
\hline \multirow[t]{2}{*}{$\begin{array}{l}\text { Questionnaire } \\
\text { Type }\end{array}$} & \multirow[t]{2}{*}{ Factor Names } & \multirow[t]{2}{*}{ Item No } & \multirow[t]{2}{*}{$\begin{array}{l}\text { Factor } \\
\text { Loadings }\end{array}$} & \multicolumn{2}{|c|}{$\begin{array}{l}\text { Grade } 10 \\
\text { Grade } 11\end{array}$} & \multicolumn{3}{|c|}{$\begin{array}{c}\text { Paired Sample } \\
t \text {-Test }\end{array}$} & \multirow{2}{*}{$\begin{array}{c}\text { Significance } \\
\text { Level } 0.05\end{array}$} \\
\hline & & & & $\mathbf{M}$ & SD & $t$ & df & SEM & \\
\hline Pre-questionnaire & \multirow{2}{*}{$\begin{array}{c}\text { Cognitive and } \\
\text { problem-solving skills }\end{array}$} & \multirow{2}{*}{6} & 0.65 & 2.75 & 0.81 & \multirow{2}{*}{7.36} & \multirow{2}{*}{416} & \multirow{2}{*}{0.08} & \multirow{2}{*}{$<0.05$} \\
\hline Post-questionnaire & & & 0.73 & 3.34 & 0.83 & & & & \\
\hline Pre-questionnaire & \multirow{2}{*}{ Critical thinking } & \multirow{2}{*}{4} & 0.72 & 2.99 & 0.83 & \multirow{2}{*}{6.11} & \multirow{2}{*}{416} & \multirow[b]{2}{*}{0.08} & \multirow{2}{*}{$<0.05$} \\
\hline Post-questionnaire & & & 0.81 & 3.55 & 0.78 & & & & \\
\hline Pre-questionnaire & \multirow{2}{*}{$\begin{array}{l}\text { The changeability of } \\
\text { scientific knowledge }\end{array}$} & \multirow{2}{*}{6} & 0.66 & 3.10 & 0.84 & \multirow{2}{*}{0.70} & \multirow{2}{*}{416} & \multirow{2}{*}{0.09} & \multirow{2}{*}{$>0.05$} \\
\hline Post-questionnaire & & & 0.74 & 3.16 & 0.90 & & & & \\
\hline Pre-questionnaire & \multirow{2}{*}{ Responsible citizenship } & \multirow[b]{2}{*}{3} & 0.70 & 2.80 & 0.85 & \multirow{2}{*}{0.24} & \multirow[b]{2}{*}{416} & \multirow[b]{2}{*}{0.08} & \multirow{2}{*}{$>0.05$} \\
\hline Post-questionnaire & & & 0.69 & 2.73 & 0.81 & & & & \\
\hline Pre-questionnaire & \multirow{2}{*}{$\begin{array}{c}\text { Mindset for } \\
\text { scientific research }\end{array}$} & \multirow{2}{*}{4} & 0.71 & 2.69 & 0.83 & \multirow{2}{*}{12.55} & \multirow{2}{*}{416} & \multirow{2}{*}{0.08} & \multirow{2}{*}{$<0.05$} \\
\hline Post-questionnaire & & & 0.60 & 3.74 & 0.88 & & & & \\
\hline
\end{tabular}

Measured using a 4-point scale, significance level 0.05; M-mean; SD—standard deviation; $\mathrm{t}$-statistics; df—the degrees of freedom; SEM-standard error of the difference.

Given the mean values within the pre-questionnaire for all the factors, perceived selfefficacy in 21st century skills ranged from 2.69 to 3.10, with an overall mean of 2.87. For all factors within the post-questionnaire, the students' perceived self-efficacy ranged from 2.73 to 3.74, with an overall mean of 3.30. This was taken to indicate that the students' perceived self-efficacy towards 21st century skills, based on the 4-point scale, was higher after the intervention. A more detailed comparison of pre- and post-questionnaire perceived selfefficacy by the experimental group of students is presented below.

\subsection{Everyday Life-Related Scenarios for Promoting 21st Century Skills}

Previous research showed that students' perceived self-efficacy towards 21st century skills varied and was often low, e.g., towards problem-solving skills [10,12]. Researchers suggested reasons for the low level of students' 21st century skills in science learning was related to the learning environment, e.g., classroom lecture or the presenting of information to the students $[15,16]$. The results of this research indicated that conducting science lessons though everyday life-related scenarios (involving mind mapping) had a positive impact on students' perceived self-efficacy towards 21st century skills. For example, in the intervention scenario Vaccination, involving a core idea related to genetic variation and focusing on cognitive and problem-solving skills, students' perceived self-efficacy towards these skills was significantly higher after the intervention (Tables 1 and 3). Thus, the implemented scenario, Vaccination, was seen as having a positive effect on students' own competence towards their use of problem-solving skills.

Encouraging active learning by enabling students to undertake a central role in their own learning (e.g., constructing mind maps related to core ideas in science in a contextbased manner) led to improvements in their perceived self-efficacy in 21st century skills. This was in line with previous research showing that, to enhance students' 21st century 
skills, teachers need to use appropriate teaching and learning methods to enhance students' engagement in the learning process [13]. This was seen as better preparing students for both higher education and the workplace $[1,7,42]$.

\subsection{Students' Perceived Self-Efficacy towards Cognitive and Problem-Solving Skills, Critical Thinking and Mindset for Scientific Research}

As an outcome of the conducted intervention, students' perceived self-efficacy towards 21st century skills was significantly higher than before the intervention in three factors-cognitive and problem-solving skills, critical thinking and mindset for scientific research. This could be explained by the fact that, in the conducted intervention, these skills were developed through everyday life-related scenarios, which included active learning opportunities, such as participating in a debate, role-play, argumentation, etc. Such active learning opportunities enabled students to make interdisciplinary connections between the skills and their gained knowledge (exhibited through mind-mapping tasks). This was in line with previous studies, which showed that, to support students' perceived self-efficacy through all science subjects, it was important to use active learning opportunities, such as posing questions in the classroom, argumentation, group projects, role-playing and debates [36,37].

The results indicated that students perceived self-efficacy towards cognitive and problem-solving skills, critical thinking and mindset for scientific research was statistically significantly higher after the conducted intervention. This could be due to the fact that, for students, it was easier to make interconnections between their gained knowledge through problem solving, critical thinking and developing a mindset for scientific research (as in the mind-mapping task). Connecting learning to everyday life, as well an appreciation of core ideas, provided a meaningful opportunity for developing these skills, especially as students solved problems that included social aspects, as well as enabling them to make decisions with both personal and societal effects [10]. Thus, it was seen as appropriate to create more learning scenarios that emphasized different dimensions to develop students' 21st century skills and to relate these to the learning content through core ideas.

\subsection{Students' Perceived Self-Efficacy towards the Changeability of Scientific Knowledge and Responsible Citizenship}

In two factors, the change was not found to be statistically significant (the changeability of scientific knowledge and responsible citizenship). Such an outcome might be because students found it difficult to interconnect these skills to their gained knowledge (seen from the mind-mapping tasks). Suggested reasons for the lack of impact of the intervention towards the changeability of scientific knowledge and responsible citizenship could be that students did not acknowledge that they possessed a clear conceptual understanding about how scientific knowledge was constructed or have knowledge about their role in the community and the world at large. This was seen as problematic because the development of these 21st century skills was shown to be important for conceptualizing and reflecting on ways of solving today's problems, such as global warming or environmental degradation $[2,4]$. A strong scientific background and understanding about society was seen as essential so as to face the many challenges in today's world, such as those related to the COVID-19 epidemic. The results suggested that more emphasis was needed on promoting student awareness of how science and 21st century skills could contribute to addressing scientific challenges.

\subsection{Experimental and Non-Experimental Group Comparison for Students' Perceived Self-Efficacy towards 21st Century Skills}

The results showed that, after the 1.5-year intervention, students' perceived selfefficacy was significantly higher in the experimental group (compared with the nonexperimental group) in relation to three key 21st century skills factors-cognitive and problem-solving skills, critical thinking and mindset for scientific research (Table 4; Appendix B). However, in two further factors, the change was not shown to be statis- 
tically significant (the changeability of scientific knowledge and responsible citizenship). These results could be explained by the fact that, in the intervention, the emphasis was on skills, which showed students' lower perceived self-efficacy on prior cognitive and problem-solving skills, critical thinking and mindset for scientific research [10]. As these skills were actively promoted during the intervention, the change in students' perceived self-efficacy was more positive. With the changeability of scientific knowledge and responsible citizenship, the students' perceived self-efficacy tended to be higher [10] and, during this intervention, these skills were promoted less. As the emphasis was not on these skills, the results showed that there was a positive change in their perceived self-efficacy after the conducted intervention, but the change was not statistically significant.

Table 4. Comparing students' perceived self-efficacy towards 21st century skills in the experimental group $(\mathrm{N}=209)$ and non-experimental group $(\mathrm{N}=162)$.

\begin{tabular}{|c|c|c|c|c|c|c|c|c|c|}
\hline \multirow{3}{*}{$\begin{array}{l}\text { Questionnaire } \\
\text { Type }\end{array}$} & \multirow{3}{*}{ Factor Names } & \multirow{3}{*}{ Item $\mathbf{N}_{\mathbf{o}}$} & \multirow{3}{*}{$\begin{array}{l}\text { Factor } \\
\text { Loadings }\end{array}$} & \multirow{2}{*}{\multicolumn{2}{|c|}{$\begin{array}{l}\text { Grade } 10 \\
\text { Grade } 11\end{array}$}} & \multirow{2}{*}{\multicolumn{3}{|c|}{$\begin{array}{c}\text { Paired Sample } \\
t \text {-Test }\end{array}$}} & \multirow{3}{*}{$\begin{array}{l}\text { Significance } \\
\text { Level } 0.05\end{array}$} \\
\hline & & & & & & & & & \\
\hline & & & & $\mathbf{M}$ & SD & $t$ & $\mathrm{df}$ & SEM & \\
\hline Experimental & \multirow{2}{*}{$\begin{array}{c}\text { Cognitive and } \\
\text { problem-solving skills }\end{array}$} & \multirow{2}{*}{6} & 0.73 & 3.34 & 0.83 & \multirow{2}{*}{7.56} & \multirow{2}{*}{369} & \multirow{2}{*}{0.09} & \multirow{2}{*}{$<0.05$} \\
\hline Non-experimental & & & 0.65 & 2.69 & 0.81 & & & & \\
\hline Experimental & \multirow{2}{*}{ Critical thinking } & \multirow{2}{*}{4} & 0.81 & 3.80 & 0.78 & \multirow{2}{*}{4.84} & \multirow{2}{*}{369} & \multirow{2}{*}{0.09} & \multirow{2}{*}{$<0.05$} \\
\hline Non-experimental & & & 0.72 & 3.39 & 0.83 & & & & \\
\hline Experimental & \multirow{2}{*}{$\begin{array}{l}\text { The changeability of } \\
\text { scientific knowledge }\end{array}$} & \multirow{2}{*}{6} & 0.74 & 3.16 & 0.90 & \multirow{2}{*}{1.86} & \multirow{2}{*}{369} & \multirow{2}{*}{0.09} & \multirow{2}{*}{$>0.05$} \\
\hline Non-experimental & & & 0.66 & 2.99 & 0.84 & & & & \\
\hline Experimental & \multirow{2}{*}{ Responsible citizenship } & \multirow{2}{*}{3} & 0.69 & 2.73 & 0.81 & \multirow{2}{*}{0.23} & \multirow{2}{*}{369} & \multirow{2}{*}{0.09} & \multirow{2}{*}{$>0.05$} \\
\hline Non-experimental & & & 0.70 & 2.75 & 0.85 & & & & \\
\hline Experimental & \multirow{3}{*}{$\begin{array}{c}\text { Mindset for } \\
\text { scientific research }\end{array}$} & \multirow{3}{*}{4} & 0.60 & 3.86 & 0.88 & \multirow{3}{*}{10.88} & \multirow{3}{*}{369} & \multirow{3}{*}{0.09} & \multirow{3}{*}{$<0.05$} \\
\hline & & & 0.71 & 2.89 & 0.83 & & & & \\
\hline Non-experimental & & & 0.71 & 2.89 & 0.83 & & & & \\
\hline
\end{tabular}

Measured using a 4-point scale; significance level 0.05; M-mean; SD—standard deviation; $\mathrm{t}$-statistics; $\mathrm{df}$-the degrees of freedom; SEM — standard error of the difference.

The results of this study indicated that, after the intervention, students had higher perceived self-efficacy towards most 21st century skills. This was seen as meaningful, and indicated that the inclusion of everyday life-related scenarios served the intended purpose of supporting the promotion of 21st century skills, at least as perceived by students.

\section{Conclusions}

Students' perceived self-efficacy towards 21st century skills after the intervention (using everyday life-related scenarios) was significantly higher than before the intervention in three factors-cognitive and problem solving, critical thinking and mindset for scientific research. In two factors, the change was not found to be statistically significant (the changeability of scientific knowledge and responsible citizenship). The results indicated that, after the intervention, students' perceived self-efficacy was higher towards most 21st century skills. The implemented method was meaningful in developing students 21st century skills when these were related to the scenario-based learning and to the creation of core idea maps.

The non-experimental group results, compared with those of the experimental group, confirmed that, after the intervention perceived self-efficacy was high towards most 21st century skills.

\section{Further Research}

The finding that students perceived self-efficacy increased for three factors is promising for further studies promoting 21st century skills. This is especially the case since previous studies have shown that students' perceived self-efficacy remains low, e.g., related 
to the utilization of problem-solving skills $[12,35]$. This is in line with previous research, which has emphasized that the integration and connecting of skills to knowledge can have a positive effect on the development of students' 21st century skills, such as problem solving and decision making $[8,15,24]$. For this, it is important to further research how students conceptualize core ideas and link knowledge and 21st century skills to these. To achieve this, one proposed approach is to analyze, in greater depth, students' created core idea maps

\section{Recommendations}

In order for science education to be more integrated with real-life situations, more attention needs to be paid to teaching approaches. Based on these research outcomes, it is important that the content of the teaching material is more closely related to everyday situations and the ways in which science content is connected to 21 st century skills. It is recommended that a learning environment needs to support student learning with purposefully developed meaningful activities, such as implementing everyday life-related scenarios, including creating core idea maps (following the mind-mapping method) and through active learning approaches.

\section{Limitations}

This research involved a small student sample size and the schools included were a convenient sample. Therefore, results cannot not be generalizable for the whole population. Despite this, the results provided valuable insights for integrating and conceptualizing science content through the promotion of 21st century skills.

The conducted intervention was intensive because it was administered within a short period of time. More dispersed activities over a longer time span would be expected to give students extra time to strengthen their 21st century skills.

In this study, the data were analyzed only by the use of Mplus program and CFA. To better describe the data in future studies, and to analyze and interpretation the data more carefully, R can be used to allow the development of ordered-probit models and conducting of Bayesian analysis [43].

In addition, several items (such as the so-called soft skills, e.g., collaboration and teamwork) were omitted from the final factor structure, based on their low factor loadings in different factors.

Author Contributions: Conceptualization, H.S., R.S. and M.R.; Formal analysis, H.S.; Methodology, H.S.; Supervision, R.S. and M.R.; Writing - original draft, H.S.; Writing - review \& editing, H.S., R.S. and M.R. All authors have read and agreed to the published version of the manuscript.

Funding: The research was supported by European Social Fund, project 2014-2020.1.02.18-0645 (Enhancement of Research and Development Capability of Teacher Education Competence Centre Pedagogicum).

Institutional Review Board Statement: Ethical review and approval were waved for this study, due to the study being part of a project for which ethical approval had been obtained from the University of Tartu.

Informed Consent Statement: Informed consent was obtained from all subjects involved in the study.

Data Availability Statement: Data are available on request due to restrictions, e.g., privacy or ethical. The data presented in this study are available on request from the corresponding author. The data are not publicly available due to privacy protection of participants.

Acknowledgments: The authors are thankful for all partners, teachers and students who participated in this research, as well as members of the research team who supported the study.

Conflicts of Interest: The authors declare no conflict of interest. 


\section{Appendix A}

Table A1. Experimental group ( $\mathrm{N}=209)$ pre- and post-questionnaire CFA comparison on perceived self-efficacy towards 21st century skills.

\begin{tabular}{|c|c|c|c|c|c|c|c|c|c|c|}
\hline \multirow{2}{*}{ 21st Century Skills } & \multirow{2}{*}{$\begin{array}{l}\text { Factor Loads } \\
\text { Pre- }\end{array}$} & \multirow{2}{*}{$\begin{array}{l}\text { Factor Loads } \\
\text { Post- }\end{array}$} & \multirow{2}{*}{$\begin{array}{c}\text { Pre- } \\
\mathbf{M}\end{array}$} & \multirow{2}{*}{ SD } & \multicolumn{2}{|c|}{ Post- } & \multicolumn{3}{|c|}{$\begin{array}{l}\text { Paired Sample } \\
t \text {-Test }\end{array}$} & \multirow{2}{*}{$\begin{array}{l}\text { Significance } \\
\text { Level } 0.05\end{array}$} \\
\hline & & & & & $\mathbf{M}$ & SD & $t$ & df & SEM & \\
\hline \multicolumn{11}{|c|}{ Cognitive and problem-solving skills (f1) } \\
\hline $\begin{array}{l}\text { I can use creative thinking to solve } \\
\text { scientific problems }\end{array}$ & \multirow{6}{*}{0.65} & \multirow{6}{*}{0.73} & 2.93 & 0.82 & 3.33 & 0.84 & 4.93 & 416 & 0.08 & $<0.05$ \\
\hline $\begin{array}{l}\text { Before I start to solve problems, I make sure } \\
\text { whether the problem is within my level of } \\
\text { understanding or whether I need extra help }\end{array}$ & & & 2.62 & 0.80 & 3.57 & 0.88 & 11.55 & 416 & 0.08 & $<0.05$ \\
\hline $\begin{array}{l}\text { I evaluate the efforts and the effectiveness of a } \\
\text { selected strategy even when I do not reach the } \\
\text { desired goal }\end{array}$ & & & 2.93 & 0.80 & 3.52 & 0.79 & 7.59 & 416 & 0.08 & $<0.05$ \\
\hline $\begin{array}{l}\text { I can design the most appropriate strategy to } \\
\text { solve problems }\end{array}$ & & & 2.67 & 0.82 & 2.95 & 0.80 & 3.53 & 416 & 0.08 & $<0.05$ \\
\hline $\begin{array}{l}\text { I can find alternative strategies if an initial } \\
\text { approach does not work }\end{array}$ & & & 2.79 & 0.80 & 2.99 & 0.96 & 2.31 & 416 & 0.09 & $<0.05$ \\
\hline I am motivated to solve challenging problems & & & 2.56 & 0.81 & 3.69 & 0.69 & 15.35 & 416 & 0.07 & $<0.05$ \\
\hline \multicolumn{11}{|c|}{ Critical thinking (f2) } \\
\hline $\begin{array}{l}\text { I can critically evaluate the } \\
\text { quality of information }\end{array}$ & \multirow{3}{*}{0.72} & \multirow[t]{3}{*}{0.81} & 2.90 & 0.83 & 3.90 & 0.88 & 11.95 & 416 & 0.08 & $<0.05$ \\
\hline $\begin{array}{l}\text { I can distinguish scientific evidence } \\
\text { from non-scientific }\end{array}$ & & & 3.00 & 0.79 & 3.65 & 0.80 & 8.36 & 416 & 0.08 & $<0.05$ \\
\hline $\begin{array}{l}\text { Creativity and imagination are important } \\
\text { factors for establishing scientific knowledge }\end{array}$ & & & 3.07 & 0.82 & 3.51 & 0.75 & 5.72 & 416 & 0.08 & $<0.05$ \\
\hline
\end{tabular}


Table A1. Cont.

\begin{tabular}{|c|c|c|c|c|c|c|c|c|c|c|}
\hline \multirow{2}{*}{ 21st Century Skills } & \multirow{2}{*}{$\begin{array}{l}\text { Factor Loads } \\
\text { Pre- }\end{array}$} & \multirow{2}{*}{$\begin{array}{l}\text { Factor Loads } \\
\text { Post- }\end{array}$} & \multirow{2}{*}{$\begin{array}{c}\text { Pre- } \\
\mathrm{M}\end{array}$} & \multirow{2}{*}{ SD } & \multicolumn{2}{|c|}{ Post- } & \multicolumn{3}{|c|}{$\begin{array}{l}\text { Paired Sample } \\
t \text {-Test }\end{array}$} & \multirow{2}{*}{$\begin{array}{l}\text { Significance } \\
\text { Level } 0.05\end{array}$} \\
\hline & & & & & $\mathbf{M}$ & SD & $\mathbf{t}$ & df & SEM & \\
\hline \multicolumn{11}{|c|}{ The changeability of scientific knowledge (f3) } \\
\hline $\begin{array}{l}\text { I try to understand the reasons for other } \\
\text { peoples' actions instead of judging them }\end{array}$ & \multirow{5}{*}{0.67} & \multirow{5}{*}{0.74} & 3.16 & 0.88 & 3.31 & 0.90 & 1.72 & 416 & 0.09 & $>0.05$ \\
\hline $\begin{array}{l}\text { I show respect for other human beings } \\
\text { regardless of their cultural backgrounds } \\
\text { and nationalities }\end{array}$ & & & 3.12 & 0.90 & 3.45 & 0.95 & 3.65 & 416 & 0.09 & $<0.05$ \\
\hline In my opinion scientific knowledge can change & & & 3.28 & 0.82 & 3.03 & 0.90 & 2.97 & 416 & 0.08 & $<0.05$ \\
\hline $\begin{array}{l}\text { I can explain natural phenomena } \\
\text { in everyday life }\end{array}$ & & & 2.85 & 0.83 & 2.93 & 0.86 & 0.97 & 416 & 0.08 & $>0.05$ \\
\hline $\begin{array}{l}\text { The usefulness of scientific knowledge depends } \\
\text { on how and for what purpose they are used }\end{array}$ & & & 3.07 & 0.79 & 3.10 & 0.88 & 0.37 & 416 & 0.08 & $>0.05$ \\
\hline \multicolumn{11}{|c|}{ Responsible citizenship (f4) } \\
\hline $\begin{array}{l}\text { When I make decisions, I consider the positive } \\
\text { and negative consequences towards the } \\
\text { natural environment }\end{array}$ & \multirow{4}{*}{0.70} & \multirow{4}{*}{0.69} & 2.72 & 0.89 & 2.83 & 0.85 & 1.29 & 416 & 0.09 & $>0.05$ \\
\hline $\begin{array}{l}\text { My personal well-being is connected to what } \\
\text { happens in nature at a global level }\end{array}$ & & & 2.74 & 0.90 & 2.76 & 0.83 & 0.24 & 416 & 0.09 & $>0.05$ \\
\hline $\begin{array}{c}\text { In future, I would like to work in a position } \\
\text { where I can contribute to protecting the } \\
\text { natural environment }\end{array}$ & & & 2.42 & 0.82 & 2.40 & 0.82 & 0.25 & 416 & 0.08 & $>0.05$ \\
\hline $\begin{array}{l}\text { In problem-solving, I am sensitive to ethical } \\
\text { standards which are valued by society }\end{array}$ & & & 2.66 & 0.80 & 2.64 & 0.82 & 0.25 & 416 & 0.08 & $>0.05$ \\
\hline
\end{tabular}


Table A1. Cont.

\begin{tabular}{|c|c|c|c|c|c|c|c|c|c|c|}
\hline \multirow{2}{*}{ 21st Century Skills } & \multirow{2}{*}{$\begin{array}{l}\text { Factor Loads } \\
\text { Pre- }\end{array}$} & \multirow{2}{*}{$\begin{array}{l}\text { Factor Loads } \\
\quad \text { Post- }\end{array}$} & \multirow{2}{*}{$\begin{array}{l}\text { Pre- } \\
\text { M }\end{array}$} & \multirow{2}{*}{ SD } & \multicolumn{2}{|c|}{ Post- } & \multicolumn{3}{|c|}{$\begin{array}{l}\text { Paired Sample } \\
t \text {-Test }\end{array}$} & \multirow{2}{*}{$\begin{array}{l}\text { Significance } \\
\text { Level } 0.05\end{array}$} \\
\hline & & & & & $\mathbf{M}$ & SD & $\mathbf{t}$ & df & SEM & \\
\hline \multicolumn{11}{|c|}{ Mindset for scientific research (f5) } \\
\hline $\begin{array}{l}\text { In my opinion, scientific models (like DNA) } \\
\text { portray nature as it actually exists }\end{array}$ & \multirow{4}{*}{0.71} & \multirow{4}{*}{0.60} & 2.79 & 0.83 & 3.69 & 0.90 & 10.63 & 416 & 0.09 & $<0.05$ \\
\hline $\begin{array}{l}\text { In my opinion, carefully collected data gives } \\
\text { perfect knowledge }\end{array}$ & & & 2.95 & 0.85 & 3.99 & 0.90 & 12.15 & 416 & 0.09 & $<0.05$ \\
\hline $\begin{array}{l}\text { In my opinion, there is only one certain } \\
\text { scientific method for creating } \\
\text { scientific knowledge }\end{array}$ & & & 2.89 & 0.83 & 3.57 & 0.86 & 8.23 & 416 & 0.08 & $<0.05$ \\
\hline $\begin{array}{l}\text { I can apply knowledge from science lessons in } \\
\text { new situations }\end{array}$ & & & 2.94 & 0.81 & 3.72 & 0.87 & 9.49 & 416 & 0.08 & $<0.05$ \\
\hline
\end{tabular}

Measured using a 4-point scale; significance level 0.05; M-mean; SD—standard deviation; $t$-statistics; df-the degrees of freedom; SEM-standard error of the difference. 


\section{Appendix B}

Table A2. Students' perceived self-efficacy towards 21st century skills; experimental schools' students $(\mathrm{N}=209)$ and non-experimental schools' $(\mathrm{N}=162)$ results comparison.

\begin{tabular}{|c|c|c|c|c|c|c|c|c|c|c|}
\hline \multirow{2}{*}{ 21st Century Skills } & \multirow{2}{*}{$\begin{array}{c}\text { Non- } \\
\text { experimental }\end{array}$} & \multirow{2}{*}{ Experimental } & \multirow{2}{*}{$\begin{array}{c}\begin{array}{c}\text { Non- } \\
\text { experimental }\end{array} \\
\mathbf{M}\end{array}$} & \multirow{2}{*}{ SD } & \multicolumn{2}{|c|}{ Experimental } & \multicolumn{3}{|c|}{ Paired Sample $t$-Test } & \multirow{2}{*}{$\begin{array}{l}\text { Significance } \\
\text { Level } 0.05\end{array}$} \\
\hline & & & & & $\mathbf{M}$ & SD & $t$ & $\mathrm{df}$ & SEM & \\
\hline \multicolumn{11}{|c|}{ Cognitive and problem-solving skills (f1) } \\
\hline $\begin{array}{l}\text { I can use creative thinking to solve } \\
\text { scientific problems }\end{array}$ & & & 3.02 & 0.75 & 3.33 & 0.84 & 3.69 & 369 & 0.08 & $<0.05$ \\
\hline $\begin{array}{l}\text { Before I start to solve problems, I make sure } \\
\text { whether the problem is within my level of } \\
\text { understanding or I need extra help }\end{array}$ & & & 2.73 & 0.84 & 3.57 & 0.88 & 9.30 & 369 & 0.09 & $<0.05$ \\
\hline $\begin{array}{l}\text { I evaluate the efforts and the effectiveness of a } \\
\text { selected strategy even when I do not reach the } \\
\text { desired goal }\end{array}$ & 0.60 & 0.73 & 3.12 & 0.68 & 3.52 & 0.79 & 5.14 & 369 & 0.08 & $<0.05$ \\
\hline $\begin{array}{l}\text { I can design the most appropriate strategy to } \\
\text { solve problem }\end{array}$ & & & 2.87 & 0.78 & 2.95 & 0.80 & 0.97 & 369 & 0.08 & $>0.05$ \\
\hline $\begin{array}{l}\text { I can find alternative strategies if an initial } \\
\text { strategy does not work }\end{array}$ & & & 2.89 & 0.92 & 2.99 & 0.96 & 1.01 & 369 & 0.10 & $>0.05$ \\
\hline I am motivated to solve challenging problems & & & 3.16 & 0.69 & 3.69 & 0.69 & 7.34 & 369 & 0.07 & $<0.05$ \\
\hline \multicolumn{11}{|c|}{ Critical thinking (f2) } \\
\hline $\begin{array}{l}\text { I can critically evaluate the } \\
\text { quality of information }\end{array}$ & 0.65 & 0.81 & 3.14 & 0.75 & 3.90 & 0.88 & 8.79 & 369 & 0.09 & $<0.05$ \\
\hline $\begin{array}{l}\text { I can distinguish scientific evidence from } \\
\text { that non-scientific }\end{array}$ & & & 3.21 & 0.70 & 3.65 & 0.80 & 5.55 & 369 & 0.08 & $<0.05$ \\
\hline $\begin{array}{l}\text { Creativity and imagination are important } \\
\text { factors for establishing scientific knowledge }\end{array}$ & & & 3.87 & 0.62 & 3.91 & 0.75 & 0.56 & 369 & 0.07 & $>0.05$ \\
\hline
\end{tabular}


Table A2. Cont.

\begin{tabular}{|c|c|c|c|c|c|c|c|c|c|c|}
\hline \multirow{2}{*}{ 21st Century Skills } & \multirow{2}{*}{$\begin{array}{c}\text { Non- } \\
\text { experimental }\end{array}$} & \multirow{2}{*}{ Experimental } & \multirow{2}{*}{$\begin{array}{c}\begin{array}{c}\text { Non- } \\
\text { experimental }\end{array} \\
\mathbf{M}\end{array}$} & \multirow{2}{*}{ SD } & \multicolumn{2}{|c|}{ Experimental } & \multicolumn{3}{|c|}{ Paired Sample $t$-Test } & \multirow{2}{*}{$\begin{array}{l}\text { Significance } \\
\text { Level } 0.05\end{array}$} \\
\hline & & & & & $\mathbf{M}$ & SD & $\mathbf{t}$ & df & SEM & \\
\hline \multicolumn{11}{|c|}{ The changeability of scientific knowledge (f3) } \\
\hline $\begin{array}{l}\text { I try to understand the reasons for other } \\
\text { peoples' actions instead of judging them }\end{array}$ & \multirow{5}{*}{0.72} & \multirow{5}{*}{0.74} & 3.16 & 0.82 & 3.31 & 0.90 & 1.65 & 369 & 0.09 & $>0.05$ \\
\hline $\begin{array}{l}\text { I show respect for other human beings } \\
\text { regardless of their cultural backgrounds } \\
\text { and nationalities }\end{array}$ & & & 3.23 & 0.80 & 3.45 & 0.95 & 2.37 & 369 & 0.09 & $<0.05$ \\
\hline In my opinion scientific knowledge can change & & & 2.88 & 0.91 & 3.03 & 0.90 & 1.58 & 369 & 0.10 & $>0.05$ \\
\hline $\begin{array}{l}\text { I can explain natural phenomena in } \\
\text { everyday life }\end{array}$ & & & 2.85 & 0.67 & 2.93 & 0.86 & 0.98 & 369 & 0.08 & $>0.05$ \\
\hline $\begin{array}{l}\text { The usefulness of scientific knowledge depends } \\
\text { on how and for what purpose it is used }\end{array}$ & & & 2.87 & 0.72 & 3.10 & 0.88 & 2.70 & 369 & 0.09 & $<0.05$ \\
\hline \multicolumn{11}{|c|}{ Responsible citizenship (f4) } \\
\hline $\begin{array}{c}\text { When I make decisions, I consider the positive } \\
\text { and negative consequences towards the } \\
\text { natural environment }\end{array}$ & \multirow{4}{*}{0.74} & \multirow{4}{*}{0.69} & 2.68 & 0.79 & 2.83 & 0.85 & 1.74 & 369 & 0.09 & $>0.05$ \\
\hline $\begin{array}{l}\text { My personal well-being is connected to what } \\
\text { happens in nature at a global level }\end{array}$ & & & 2.65 & 0.92 & 2.76 & 0.83 & 2.21 & 369 & 0.09 & $>0.05$ \\
\hline $\begin{array}{c}\text { In future, I would like to work in a position } \\
\text { where I could contribute to protecting the } \\
\text { natural environment }\end{array}$ & & & 2.32 & 0.88 & 2.40 & 0.82 & 0.90 & 369 & 0.09 & $>0.05$ \\
\hline $\begin{array}{l}\text { In problem-solving, I am sensitive to ethical } \\
\text { standards which are valued by society }\end{array}$ & & & 2.67 & 0.82 & 2.64 & 0.82 & 0.35 & 369 & 0.09 & $>0.05$ \\
\hline
\end{tabular}


Table A2. Cont.

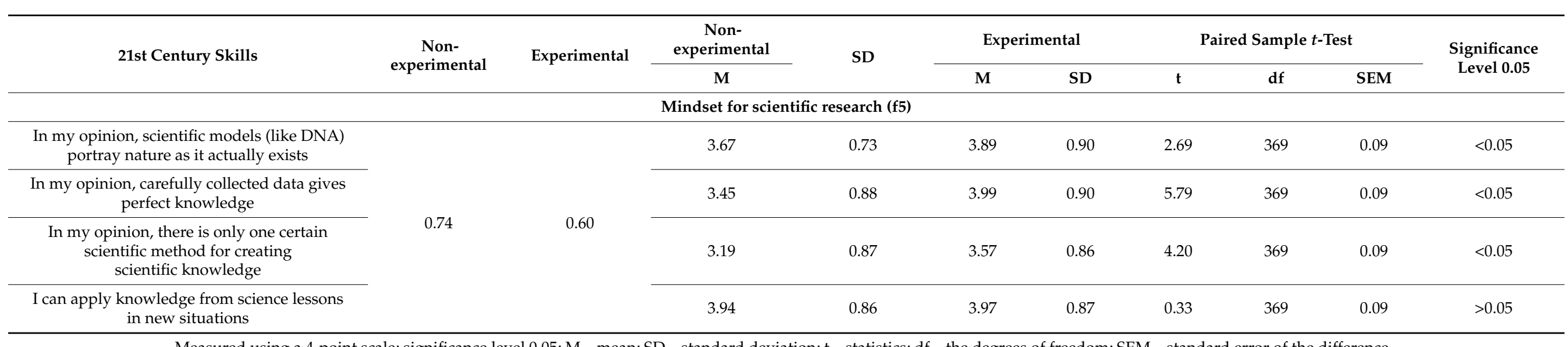

Measured using a 4-point scale; significance level 0.05; M-mean; SD—standard deviation; $t$-statistics; df-the degrees of freedom; SEM-standard error of the difference. 


\section{References}

1. Van Laar, E.; Van Deursen, A.J.; Van Dijk, J.A.; De Haan, J. The relation between 21st century skills and digital skills: A systematic literature review. Comput. Hum. Behav. 2017, 72, 577-588. [CrossRef]

2. OECD. Pisa 2018 (Volume I) Results: What Students Know and Can Do; OECD Publishing: Paris, France, 2019. [CrossRef]

3. Rios, J.A.; Ling, G.; Pugh, R.; Becker, D.; Bacall, A. Identifying Critical 21st Century Skills for Workplace Success: A Content Analysis of Job Advertisements. SAGE J. 2020, 49, 80-89. [CrossRef]

4. Partnership for 21st Century Skills (P21). A Framework for Twenty-First Century Learning. 2009. Available online: http: //www.o21.org/ (accessed on 20 April 2021).

5. Amzaleg, M.; Masry-Herzallah, A. Cultural dimensions and skills in the 21st century: The Israeli education system as a case study. Pedagog. Cult. Soc. 2021, 1-21. [CrossRef]

6. Chalkiadaki, A. A Systematic Literature Review of 21st Century Skills and Competencies in Primary Education. Int. J. Instr. 2018, 11, 1-16. [CrossRef]

7. Chu, S.K.W.; Reynolds, B.; Tavares, N.J.; Notari, M.; Lee, C.W.Y. 21st Century Skills Development through Inquiry-Based Learning from Theory to Practice; Springer: Berlin, Germany, 2017.

8. Scoular, C.; Teo, I. Developing strategic plans for an aligned approach to 21st century skills integration. Aust. Counc. Educ. Res. (ACER) 2021. [CrossRef]

9. Bandura, A. Social Foundations of Thought and Action: A Social Cognitive Theory; Prentice-Hall: Englewood Cliffs, NJ, USA, 1986.

10. Semilarski, H.; Soobard, R.; Rannikmäe, M. Modeling Students' Perceived Self-Efficacy and Importance towards Core Ideas and Work and Life Skills in Science Education. Sci. Educ. Int. 2019, 30, 261-273. [CrossRef]

11. Badcock, P.B.T.; Pattison, P.E.; Harris, K.-L. Developing generic skills through university study: A study of arts, science and engineering in Australia. High. Educ. 2010, 60, 441-458. [CrossRef]

12. Evans, T.; Thomas, M.O.J.; Klymchuk, S. Non-routine problem solving through the lens of self-efficacy. High. Educ. Res. Dev. 2020, 1-18. [CrossRef]

13. Gillies, R.M.; Nichols, K.; Burgh, G.; Haynes, M. Primary Students' Scientific Reasoning and Discourse during Cooperative Inquiry-Based Science Activities. Int. J. Educ. Res. 2014, 63, 127140. [CrossRef]

14. Nouri, J.; Zhang, L.; Mannila, L.; Norén, E. Development of computational thinking, digital competence and 21st century skills when learning programming in K-9. Educ. Inq. 2019, 11, 1-17. [CrossRef]

15. Scalise, K. Student collaboration and school educational technology: Technology integration practices in the classroom. J. Sch. Educ. Technol. 2016, 11, 53-63. [CrossRef]

16. Stehle, S.M.; Peters-Burton, E.E. Developing student 21st Century skills in selected exemplary inclusive STEM high schools. Int. J. STEM Educ. 2019, 6, 1-15. [CrossRef]

17. Haug, B.S.; Mork, S.M. Taking 21st century skills from vision to classroom: What teachers highlight as supportive professional development in the light of new demands from educational reforms. Teach. Teach. Educ. 2021, 1000, 103286. [CrossRef]

18. Tight, M. Twenty-first century skills: Meaning, usage and value. Eur. J. High. Educ. 2021, 11, 160-174. [CrossRef]

19. Choi, K.; Lee, H.; Shin, N.; Kim, S.; Krajcik, J. Re-Conceptualization of scientific literacy in South Korea for the 21st century. J. Res. Sci. Teach. 2011, 48, 670-697. [CrossRef]

20. Geisinger, K.F. 21st Century Skills: What Are They and How Do We Assess Them? Appl. Meas. Educ. 2016, 29, 245-249. [CrossRef]

21. Garía-Pérez, L.; García-Garnica, M.; Olmedo-Moreno, E.M. Skills for a Working Future: How to Bring about Professional Success from the Educational Setting. Educ. Sci. 2021, 11, 27. [CrossRef]

22. Binkley, M.; Erstad, O.; Herman, J.; Raizen, S.; Ripley, M.; Miller-Ricci, M.; Rumble, M. Defining 21st century skills. In Assessment and Teaching of 21st Century Skills; McGaw, B., Care, E., Eds.; Springer: New York, NY, USA, 2012; pp. 17-66.

23. Semilarski, H.; Soobard, R.; Holbrook, J.; Rannikmäe, M. Grade 8 and 11 students' science and science-related career profiles. In EDULEARN19 PROCEEDINGS; IATED Academy: Valencia, Spain, 2019; pp. 6312-6319.

24. Haatainen, O.; Turkka, J.; Aksela, M. Science Teachers' Perceptions and Self-Efficacy Beliefs Related to Integrated Science Education. Educ. Sci. 2021, 11, 272. [CrossRef]

25. Salonen, A.; Hartikainen-Ahia, A.; Hense, J.; Scheersoi, A.; Keinonen, T. Secondary school students' perceptions of working life skills in science-related careers. Int. J. Sci. Educ. 2017, 39, 1339-1352. [CrossRef]

26. Lin, L.; Shadiev, R.; Hwang, W.-Y.; Shen, S. From knowledge and skills to digital works: An application of design thinking in the information technology course. Think. Skills Creat. 2020, 36, 100646. [CrossRef]

27. Semilarski, H.; Soobard, R.; Holbrook, J.; Rannikmäe, M. Exploring the Complexity of Student-Created Mind Maps, Based on Science-Related Disciplinary and Interdisciplinary Core Ideas. Interdiscip. J. Environ. Sci. Educ. 2021, 17, e2227. [CrossRef]

28. Santaolall, E.; Urosa, B.; Martin, O.; Verde, A.; Diaz, T. Interdisciplinarity in Teacher Education: Evaluation of the Effectiveness of an Educational Innovation Project. Sustainability 2020, 12, 6748. [CrossRef]

29. Anagun, S.S. Teachers' Perceptions about the Relationship between 21st Century Skills and Managing Constructivist Learning Environments. Int. J. Instr. 2018, 11, 825-840. [CrossRef]

30. Semilarski, H.; Soobard, R.; Semilarski, H.; Laius, A.; Rannikmäe, M. Using genetic variation as an disciplinary core idea in science education. In INTED 2020 Proceedings; Gómez Chova, L., Martínez, L.A., Candel Torres, I., Eds.; IATED Academy: Valencia, Spain, 2020; pp. 5423-5429.

31. Krajcik, J.; Delen, I. Engaging learners in STEM education. Est. J. Educ. 2017, 5, 35-58. [CrossRef] 
32. Drake, S.M.; Reid, J.L. 21st Century Competencies in Light of the History of Integrated Curriculum. Front. Educ. Leadersh. Educ. 2020, 5, 122. [CrossRef]

33. Sormunen, K.; Hartikainen-Ahia, A.; Jäppinen, I. Quality of SSI scenarios designed by science teachers. In Cognitive and Affective Aspects in Science Education Research; Hahl, K., Juuti, K., Lampiselkä, J., Uitto, A., Lavonen, J., Eds.; Springer: Cham, Switzerland, 2017; pp. 103-116.

34. Soobard, R.; Semilarski, H.; Holbrook, J.; Rannikmäe, M. Grade 12 Students' Perceived Self-efficacy Towards Working Life Skills and Curriculum Content Promoted Through Science Education. J. Balt. Sci. Educ. 2018, 17, 838-850. [CrossRef]

35. Talmi, I.; Hazzan, O.; Katz, R. Intrinsic motivation and 21st century skills in an undergraduate engineering project: The formula student project. High. Educ. Stud. 2018, 8, 46-58. [CrossRef]

36. Kohen, Z.; Herscovitz, O.; Dori, Y.J. How to promote chemical literacy? On-line question posing and communicating with scientists. Chem. Educ. Res. Prac. 2020, 21, 250-266. [CrossRef]

37. Semilarski, H.; Soobard, R.; Rannikmäe, M. Using Student-Created Core Idea Maps to Promote Meaningful Learning in Science. J. STEM Educ. 2021. submitted.

38. Dhindsa, H.S.; Makarimi-Kaim; Anderson, O.R. Constructivist-visual mind map teaching approach the quality of students' cognitive structure. J. Sci. Educ. Technol. 2010, 20, 186-200. [CrossRef]

39. Muthén, L.K.; Muthén, B.O. Mplus User's Guide, 7th ed.; Muthén and Muthén: Los Angeles, CA, USA, 2012.

40. Estonian Government. National Curriculum for Gymnasium. Regulation of the Government of the Republic of Estonia, Tallinn. 2011. Available online: https:/ / www.riigiteataja.ee/akt/174787 (accessed on 22 May 2021).

41. Lewis, T.F. Evidence regarding the internal structure: Confirmatory factor analysis. Meas. Eval. Couns. Dev. 2017, 50, 239-247. [CrossRef]

42. Rodrigues, A.L.; Cerdeira, L.; Machado-Taylor, M.D.L.; Alves, H. Technological Skills in Higher Education—Different Needs and Different Uses. Educ. Sci. 2021, 11, 326. [CrossRef]

43. Liddell, T.M.; Kruschke, J.K. Analyzing ordinal data with metric models: What could possibly go wrong? J. Exp. Soc. Psychol. 2018, 79, 328-348. [CrossRef] 